\title{
OPEN
}

\section{Author Correction: Spectrally filtered passive Si photodiode array for on-chip fluorescence imaging of intracellular calcium dynamics}

Zheshun Xiong, Fuu-Jiun Hwang, Feng Sun, Yaowei Xie, Dacheng Mao, Geng-Lin Li \& Guangyu Xu(i)

Correction to: Scientific Reports https://doi.org/10.1038/s41598-019-45563-8, published online 24 June 2019

This Article contains errors in the reference list where references 1-3 should be listed as references 9-11, and references $4-11$ should be listed as references 1-8.

Additionally, there is an error in the Author Contributions where,

“Z.X. and F.-J.H. performed the Ca2+ imaging experiments."

should read:

“Z.X. and F.-J.H. performed the $\mathrm{Ca}^{2+}$ imaging experiments."

(1) Open Access This article is licensed under a Creative Commons Attribution 4.0 International (c) License, which permits use, sharing, adaptation, distribution and reproduction in any medium or format, as long as you give appropriate credit to the original author(s) and the source, provide a link to the Creative Commons license, and indicate if changes were made. The images or other third party material in this article are included in the article's Creative Commons license, unless indicated otherwise in a credit line to the material. If material is not included in the article's Creative Commons license and your intended use is not permitted by statutory regulation or exceeds the permitted use, you will need to obtain permission directly from the copyright holder. To view a copy of this license, visit http://creativecommons.org/licenses/by/4.0/.

(C) The Author(s) 2020 